\title{
Communication/Comunicação
}

\section{First report of Eratyrus mucronatus, Stal, 1859, (Hemiptera, Reduviidae, Triatominae), in the State of Rondônia, Brazil}

\author{
Primeiro relato de ocorrência da espécie Eratyrus mucronatus, Stal, 1859, (Hemiptera, \\ Reduviidae, Triatominae), no Estado de Rondônia
}

\section{Dionatas Ulises de Oliveira Meneguetti ${ }^{1}$, Olzeno Trevisan ${ }^{2}$, Renato Moreira Rosa ${ }^{3}$ and Luís Marcelo Aranha Camargo ${ }^{4,5}$}

\begin{abstract}
Introduction: This paper reports, for the first time, the presence of the Eratyrus mucronatus species in the State of Rondonia, Brazil. Methods: These specimens were caught by chance in the forest and later they were collected using luminous traps. Results: After finding these specimens, the number of the Triatominae genera in Rondonia rose to four, while its species rose to seven. Conclusions: Complimentary studies will be conducted in order to allow for clearer understanding the ecology of this arthropod, its possible role in transmitting Chagas' disease and its current geographical distribution.
\end{abstract} Keywords: Triatominae. Eratyrus mucronatus. Rondonia.

\section{RESUMO}

Introdução: O presente comunicado relata pela primeira vez a ocorrência da espécie Eratyrus mucronatus, no Estado de Rondônia. Métodos: Os espécimes foram coletados ao acaso na mata e depois com a ajuda de armadilhas luminosas. Resultados: Com o encontro dos espécimes, o registro de gêneros de triatomíneos em Rondônia passa para quatro e o de espécies para sete. Conclusões: Estudos complementares serão realizados para compreender melhor a ecologia do artrópodo, seu eventual papel da transmissão da doença de Chagas e sua real distribuição geográfica.

Palavras-chaves: Triatomíneos. Eratyrus mucronatus. Rondônia.

The triatominae, commonly known as kissing bugs, are insects widely known by the rural populations of many regions of Brazil. Featuring variable sizes and colors, they are often mistaken for Reduviidae (Assassin bugs). These insects are widely spread throughout the Americas and are found from the South of the United States through the South of Argentina. They are important, as they may transmit Southern American trypanosomiasis, which is also called Chagas' disease ${ }^{1}$.

Although the first specie (Cimex rubrofasciatus, and ultimately Triatoma rubrofasciate De Geer, 1773) was described at the end of the $18^{\text {th }}$ Century, human contact of this insect occurred a lot earlier ${ }^{2,3}$.

1. Department of Health, Faculty of Education and the Environment, Ariquemes, RO, Brazil. 2. Department of Entomology, Executive Planning Commission of Cocoa Farming, Experimental Station, Ouro Preto do Oeste, RO, Brazil. 3. Department of Genetics and Toxicology, Lutheran University of Brazil, Canoas, RS, Brazil. 4. Department of Tropical Medicine, Institute of Biomedical Sciences V, University of São Paulo, Monte Negro, RO, Brazil. 5. Department of Medicine, São Lucas Faculty, Porto Velho, RO, Brazil.

Address to: Esp. Dionatas Ulises de Oliveira Meneguetti. Depto ${ }^{\circ}$ Saúde/FAEMA. Av. Machadinho 4349, Setor 06, 76873-630 Ariquemes, RO, Brazil.

Phone: $55693536-6600$.

e-mail: dionatasmeneguetti@hotmail.com

Received in 24/07/2010

Accepted in 11/08/2010
The first acknowledged report on the conformation and behavior of the genus Triatoma dates from 1590 and was written by the priest Reginaldo de Lizaárraga when he was making a trip to inspect the convents of Peru and Chile ${ }^{4}$. Darwin also found these insects on a trip to South America on board of the H.M.S. Beagle in $1835^{4,5}$.

Worldwide, 141 species belonging to 18 genera are known. In Brazil, 60 species belonging to 8 genera are acknowledged (Table 1) ${ }^{5}$. In the Amazonian countries, 24 species belonging to 8 genera are acknowledged ${ }^{6}$.Moreover, in the Brazilian Amazon, atleast 18 species of sylvan triatominae belonging to 8 genera have been identified, of which 10 are related to infection by the flagellate Trypanosoma $\mathrm{cruzi}^{7}$.

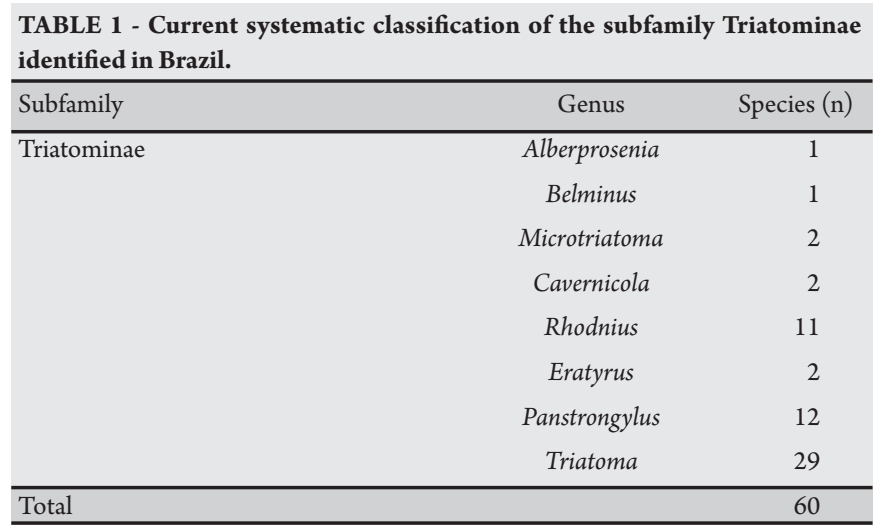

In Rondonia, the presence of six species belonging to three genera has been reported. Rhodnius robustus, Rhodnius prolixus, Rhodnius pictipes, Rhodnius milesi, Panstrongylus geniculatus and only one report on Triatoma rubrovaria ${ }^{6}$. However, this report of T. rubrovaria was possibly due to taxonomic misclassification, or resulted from an imported specimen, since it is native to Uruguay ${ }^{3}$ and the State of Rio Grande do Sul, Brazil ${ }^{5}$.

The genus Eratyrus has morphological characteristics that resemble the genus Triatoma with antennal tubercles located at the middle third of the anteocular segment; however, it presents spines and acute pronotum posterior lobe angles. This genus comprises only two species in the world, Eratyrus mucronatus and Eratyrus cuspidatus, and only the species Eratyrus mucronatus ${ }^{3,5}$ has been found in Brazil.

The Eratyrus mucronatus species has been reported in the Brazilian States of Amazonas, Para, Maranhão, Goiás, and Mato Grosso, and in neighboring countries, including Colombia, Bolivia, 
Ecuador, Guiana, French Guiana, Suriname, and Venezuela. In the State of Rondonia, it had not been identified before ${ }^{5,6}$.

This species has been found naturally infected by Trypanosoma cruzi, usually in sylvatic mammal nests in palm trees ${ }^{8}$, and has also been associated with Carvenicola pilosa $a^{9}$.

It is a species that adapts easily to stable artificial ecotones ${ }^{9}$ and the intradomiciliary presence of E. mucronatus infected by T. cruzi has been occasionally found in Bolivia ${ }^{10,11}$.

This species was first reported in the municipality of Ouro Preto do Oeste, State of Rondonia, Brazil, and was found by chance along a nature trail in a reserve of the CEPLAC -Comissão Executiva do Plano da Lavoura Cacaueira (Executive Planning Commission of Cocoa

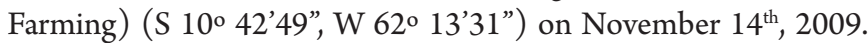

Later, four luminous traps, two Shannon and two CDC types, were set up on December $11^{\text {th }}, 12^{\text {th }}$, and $13^{\text {th }}$ of 2009 , and two more E. mucronatus species samples were caught, possibly attracted by the light of a CDC-type trap, thus proving that the sylvan triatomine species is also present in the State of Rondonia. This increases the number of species to seven, while the number of triatomine genera that have been reported in the state increased to four.

The captured triatominae were forwarded to the Laboratory of Entomology of CEPLAC, where they were identified by their external morphological conformations using a dichotomic key developed by Lent \& Wygodzinsky, $1979^{3}$.

The Eratyrus mucronatus species (Figure 1) features the following characteristics: anterior lobe of the point $1+1$, strong disc-shaped spines, humeral angle at the point are clearly spiny, corium with a relatively small subapical redish spot, which does not anteriorly reach the transversal nervure level, free portion of the convex vesica on the apex when viewed laterally ${ }^{2,5}$.

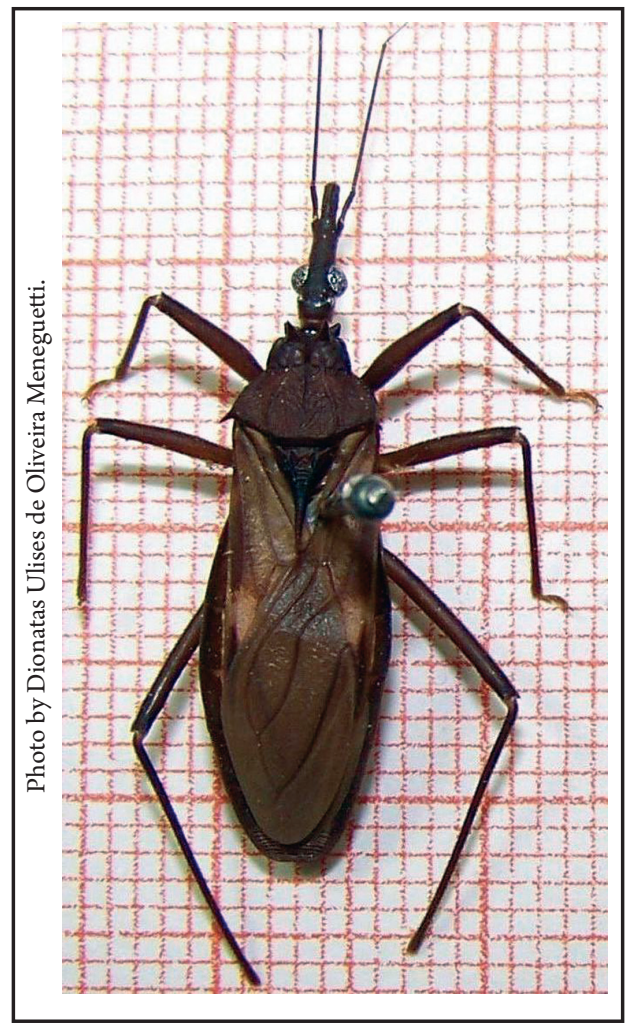

FIGURE 1 - Eratyrus mucronatus species found in the municipality of Ouro Preto do Oeste, State of Rondonia, Brazil.
The presence of more than one triatominae species in the State of Rondonia demonstrates that the biodiversity of these insects may have been underestimated and that it is important to conduct further studies regarding triatominae fauna and their distribution throughout the state, since they are vectors of Chagas' disease and could eventually jeopardize the health of the local population.

\section{CONFLICT OF INTEREST}

The authors declare that there are no conflicts of interest.

\section{REFERENCES}

1. Dias E, Dias JCP, Garcia ALR, Dias RB, Machado ENM, Gouveia SC, et al. Doença de Chagas: Textos de apoio. Brasília: Ministério da Saúde. Superintendência de Campanhas de Saúde Pública; 1989. p. 5.

2. Perfetti DJC. Triatominae de Venezuela: distribución Geográfica, aspectos taxonómicos, biológicos e importancia médica. [Doctor's Theses]. [Coro]: Tecana American University; 2007. p. 11.

3. Lent H, Wygodzinsky P. Revision of the Triatominae (Hemiptera, Reduviidae), and their significance as vectors of Chagas' disease. Bull Am Mus Nat Hist 1979; 163:127-520.

4. Galvão C. Sistemática e taxonomia clássica. [Internet]. Rio de Janeiro: Fundação Oswaldo Cruz. Ministério da Saúde; [acessado em 06/02/2010]. Disponível em <http://www.fiocruz.br/chagas/cgi/cgilua.exe/sys/start.htm?sid=84>.

5. Galvão C. Apostila - Curso de taxonomia de triatomíneos. Convênio Secretaria de Vigilância Sanitária/Fundação Oswaldo Cruz, São Luis, MA; 2007.

6. Dias JCP, Prata A, Schofield CJ. Doença de chagas na Amazônia: esboço da situação atual e perspectivas de prevenção. Rev Soc Bras Med Trop 2002; 35: 669-678.

7. Fé NF, Magalhães LK, Fé FA, Arakian SK, Monteiro WM, Barbosa MG. Ocorrência de triatomíneos em ambientes silvestres e domiciliares do município de Manaus, Estado do Amazonas. Rev Soc Bras Med Trop 2009; 42:642-646.

8. Sherlock IA, Carcavallo RU, Galíndez-Girón I. List of natural and experimental flagellates infections in several Triatominae species. In: Carcavallo RU, Galíndez Girón I, editors. Atlas of Chagas' Disease Vectors in the Americas. Rio de Janeiro: Editora Fundação Oswaldo Cruz; 1997. Vol I. p. 289-298.

9. Vivas AS, Barazarte H, Fernández DM. Primer registro de Eratyrus mucronatus Stål, 1959 (Hemiptera: Reduviidae) en el ambiente domiciliario en Venezuela. Rev Soc Venezolana Entomol 2001; 16:215-217.

10. Noireau F, Bosseno M, Carrasco R, Talleria J, Vargas F, Camacho C, et al. Sylvatic triatomines (Hemiptera: Reduviidae) and possible infection with Trypanosoma cruzi (Kinetoplastida:Trypanosomatidae). J Med Entomol 1995; 32:594-598.

11. Carcavallo RU, Rodríguez M, Salvatella R, Curto S, Scherlock I, Galvão C, et al. Habitats and related fauna. In: Carcavallo RU, Galíndez Girón I, Jurberg J, Lent H, editors. Atlas of Chagas' Disease Vectors in the Americas. Rio de Janeiro: Editora Fundação Oswaldo Cruz; 1998. Vol II. p. 561-619. 